\author{
Stanistaw Prutis ${ }^{1}$
}

\title{
Reformy agrarne w Polsce po odzyskaniu niepodległości w 1918 roku
}

\section{Uwłaszczenie chłopów na ziemiach polskich}

Nadchodzący rok 2018, będący jubileuszem stulecia odzyskania niepodległości, będzie z pewnością czasem wspomnień, historycznych ocen osiągnięć i dokonań, konsekwencji podejmowanych wówczas decyzji politycznych, gospodarczych i ustrojowych. Decyzje odbudowy Państwa Polskiego dotyczyły praktycznie wszystkich stref funkcjonowania państwa; w tym także rolnictwa - odbudowy strefy produkcyjnej rolnictwa po zniszczeniach wojennych oraz kontynuacji procesu przebudowy ustroju rolnego, zapoczątkowanych jeszcze w okresie zaborów. Tak się bowiem dzieje, że kształtowanie ustroju rolnego jest permanentnym procesem, w którym reformy agrarne stanowią swoiste okresy zmian przyspieszonych, będących impulsem czy drogowskazem. Nawiązują one zawsze do sytuacji zastanych. Tak się też złożyło, że niezwykle istotne przemiany w ustroju rolnym polskiego rolnictwa miały miejsce w ciągu wieku bezpośrednio poprzedzającego odzyskanie niepodległej państwowości. Chodzi oczywiście o reformy w postaci uwłaszczenia chłopów.

Istotne zmiany w sytuacji prawnej chłopa oraz w strukturze agrarnej ziem polskich przyniósł wiek XIX. Zmiany te nie dotyczyły tylko obszaru ziem polskich, ale całej Europy Środkowo-Wschodniej, w tym Cesarstwa Rosyjskiego. Wielki autorytet historii gospodarczej prof. Witold Kula twierdził, że: „Niewiele jest wydarzeń dziejowych równej wagi, co uwłaszczenie chłopów. Stoi ono na rubieży między tysiącletnimi dziejami wsi feudalnej a stuletnią epoką wsi kapitalistycznej. Burzy ono jedną, a tworzy nową strukturę wsi. Głębia tej przemiany jest tak wielka, że naukowcom dzisiejszym niełatwo jest ją w pełni ogarnąć".

Zdaniem A. Stelmachowskiego, uwłaszczenie chłopów było przejawem rewolucji agrarnej, która znamionowała przejście od feudalizmu do kapitalizmu; mia-

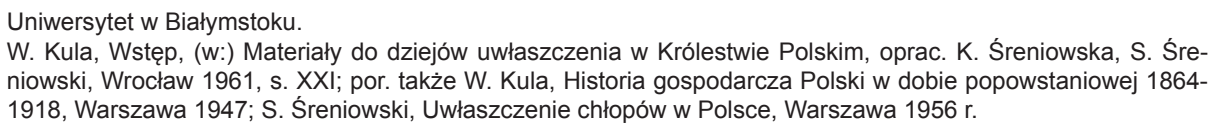
niowski, Wrocław 1961, s. XXI; por. także W. Kula, Historia gospodarcza Polski w dobie popowstaniowej 18641918, Warszawa 1947; S. Śreniowski, Uwłaszczenie chłopów w Polsce, Warszawa 1956 r. 
ła ona charakter doniosły i oznaczała zupełne przekształcenie dawnej wsi pańszczyźnianej. Taka rewolucja dokonała się na ziemiach polskich między 1807 a 1864 rokiem, a więc w okresie zaborów, przy czym zarówno jej przebieg, jak i rezultat był różny w poszczególnych dzielnicach kraju, choć przyczyny przemian agrarnych były w gruncie rzeczy takie same - sprzeczności narastające między szybko unowocześniającym się przemysłem a zacofanym rolnictwem pańszczyźnianym ${ }^{3}$.

W programach agrarnych socjaldemokracji wyodrębniano tzw. pruską drogę do kapitalizmu w rolnictwie, która charakteryzowała się zachowaniem pańszczyźnianego gospodarstwa obszarniczego, które $\mathrm{z}$ wolna przerastało w gospodarstwo kapitalistyczne ${ }^{4}$; dla stosunków polskich pruska droga do kapitalizmu w rolnictwie miała szczególne znaczenie, bo właśnie ona była realizowana przez wszystkie trzy państwa zaborcze. $Z$ tym, że warunki polityczne, w jakich realizowano uwłaszczenie chłopów, były w poszczególnych zaborach różne. W zaborze austriackim i w Królestwie Kongresowym uwłaszczenie było wymuszone ruchami rewolucyjnymi (Wiosna Ludów, powstanie styczniowe 1863 r.), podczas gdy w zaborze pruskim Wiosna Ludów przyśpieszyła końcową fazę uwłaszczenia, które przebiegało już wcześniej5.

Klasyczna pruska droga uwłaszczenia chłopów miała miejsce w zaborze pruskim. Początek reform to zniesienie poddaństwa osobistego chłopów (edyktem z 1807 r., z mocą obowiązującą od 1810 roku). Uwłaszczenie zapoczątkował edykt z 1811 r., który przewidywał uwłaszczenie stopniowo, przy jednoczesnym przerzuceniu wszelkich ciężarów ekonomicznych związanych z rekonstrukcją ustroju rolnego na chłopa. Edykt przewidywał możność przekształcenia, drogą swoiście pojętego „wykupu”, czasowych dzierżaw chłopskich w gospodarstwa dziedziczne. Od 1816 r. ograniczono regulację tylko do tzw. gospodarstw sprzężajnych ${ }^{6}$. Oznaczało to, charakterystyczną dla drogi pruskiej, rezygnację z ochrony małych gospodarstw i udzielenie wyraźnego poparcia gospodarstwom większym (górna granica chłopskiego gospodarstwa wynosiła wówczas 200 morgów magdeburskich, tj. 50 ha). Kolejnym ogniwem stopniowej reformy pruskiej był edykt z 1821 r., który pozwalał gospodarstwom sprzężajnym na wykup świadczeń pańszczyźnianych, zarówno w postaci zapłaty czynszem, jak i ziemią, jak również na całkowite uwolnienie się od zależności od pana feudalnego przez zapłatę skapitalizowanej wartości czynszu. Zawiły obraz regulacyjnego ustawodawstwa pruskiego komplikuje się jeszcze bardziej, jeśli uwzględnić różnice regionalne; np. inaczej niż na pozostałym obszarze Prus przebiegała regulacja w Poznańskiem, a jeszcze inaczej na Śląsku. Ostateczne zakończenie akcji uwłaszczenia nastąpiło w zaborze pruskim pod wpływem Wiosny

3 Por. A. Stelmachowski, (w:) J. Selwa, A. Stelmachowski, Prawo rolne, Warszawa 1970, s. 30 i n. oraz tam powołana literatura.

4 Drugą drogą była droga typu amerykańskiego, gdzie kolonizacja odbywała się na terenach wolnych, na których nie było przedtem żadnych form gospodarki feudalnej.

5 Por. A. Stelmachowski, Prawo rolne, op. cit., s. 31-32.

6 Takich, które obrabiały posiadaną ziemię parą koni lub parą wołów. 
Ludów, która zakończyła się w Niemczech feudalno-burżuazyjnym kompromisem. Od strony prawnej aktami końcowymi były trzy ustawy z lat 1848-1850; na ich podstawie uwłaszczono wszystkich posiadaczy gruntów „nienależących do folwarku”, a więc również gospodarstwa „niesprzężajne”, o ile jeszcze takie przetrwały. Wszelkie zwierzchnie prawa dworu zostały zniesione bez odszkodowania; wszelkie powinności chłopskie, jeszcze nie zamienione na renty, zamieniono na czynsze ${ }^{7}$.

Na przebieg akcji uwłaszczenia chłopów w zaborze austriackim wpływ miały zarówno ruchy narodowo-wyzwoleńcze, jak i chłopskie, zapoczątkowane w $1846 \mathrm{r}$. (powstanie krakowskie, ,rzeź galicyjska”). Gdy w 1848 r. Wiosna Ludów przyniosła kolejny przypływ ruchów rewolucyjnych, ogłoszono proklamację uwłaszczenia we Lwowie w dniu 17 kwietnia 1848 r. Uwłaszczenie objęło wszystkich chłopów, nawet tych, którzy mieli w swoim władaniu ziemię dworską, z wyłączeniem jedynie dzierżaw czasowych. Odszkodowanie dla właścicieli miało wypłacić państwo; odszkodowania były niższe od analogicznych odszkodowań pruskich. W 1853 r. wydany został patent o znoszeniu służebności; akcja ta przebiegała wszakże powoli i nie została zakończona do końca rządów zaborczych.

W Królestwie Polskim poddaństwo osobiste zostało zniesione już w 1807 r., od czasu konstytucji napoleońskiej, nadanej Księstwu Warszawskiemu; natomiast rozwiązanie kwestii agrarnej związane było z przebiegiem powstania styczniowego. Manifest Rządu Narodowego z 22 stycznia 1863 r. zawierał zasadniczy program reformy agrarnej; proklamował on przyznanie pełnej własności posiadanej ziemi bez jakichkolwiek powinności. Chłopi biorący udział w powstaniu mieli otrzymać ziemię z dóbr narodowych; odszkodowanie dla właścicieli miało wypłacać państwo. Powstanie upadło, jednak jego program agrarny okazał się silniejszy. Uwłaszczeniowy ukaz carski z 19 lutego 1864 r., wydany celem odciągnięcia chłopów od powstania, nie mógł dawać mniej, niż obiecywał Rząd Narodowy. Ukaz dawał chłopom pełną własność bez żadnych warunków i obciążeń; uwłaszczał chłopów według stanu posiadania z 1846 r., a więc umożliwiał otrzymanie ziemi wielu chłopom poprzednio wyrugowanym. Na rzecz właścicieli przewidziane było odszkodowanie, wypłacane przez państwo. Odszkodowanie było skalkulowane względnie korzystnie dla chłopów. Ujemną stroną reformy było pominięcie sprawy serwitutów; ich likwidacja nastąpiła dopiero $\mathrm{w}$ okresie międzywojennym ${ }^{8}$.

Po okresie uwłaszczenia, realizującym pierwotne kapitalistyczne koncepcje agrarne, nastąpił dłuższy okres (aż do końca I wojny światowej 1914-1918), w którym ugruntowywano powstałe stosunki kapitalistyczne na wsi, z tym że postawa poszczególnych rządów zaborczych była zróżnicowana. W zaborze austriackim przejawiał się kierunek skrajnie liberalny; do roku 1868 znikły wszelkie ogranicze-

7 Por. A. Stelmachowski, Prawo rolne, op. cit., s. 31-34.

8 Tamże, s. 34-37. 
nia w obrocie ziemią i w zakresie dziedziczenia gospodarstw rolnych. Przeciwieństwem polityki liberalnej była polityka pruska, ponieważ rząd pruski nie wyrzekł się nigdy wpływu na kształtowanie stosunków rolnych. Głównym przejawem tej polityki była akcja kolonizacji wewnętrznej o narodowościowym ostrzu (jedna z ustaw z 1912 r. nosiła nawet tytuł: „o umocnieniu niemieckości...”). Władze carskie prowadziły politykę zachowania półfeudalnego porządku rzeczy. Istniało stanowe ustawodawstwo włościańskie, regulujące własność ,włościańską"9.

Przypomnienie reguł reform uwłaszczeniowych było uzasadnione faktem, iż zdaniem R. Jastrzębskiego - reformy XIX wieku odcisnęły swoje piętno na dzisiejszej strukturze polskiej wsi. W ich wyniku bowiem powstały średniotowarowe oraz wielkotowarowe gospodarstwa rolne w zaborze pruskim oraz często karłowate w postaci tzw. szachownicy - gospodarstwa na obszarze zaboru rosyjskiego i austriackiego. Przebieg tych reform związany był z określonymi zagadnieniami, które wynikały z odpowiednich regulacji prawnych oraz prowadzonej polityki agrarnej, opartej na dwóch czynnikach: ekonomicznym i socjalnym. Do zagadnień tych R. Jastrzębski zaliczył: 1) parcelację; 2) przejęcie przez państwo na cele reformy tzw. dóbr martwej ręki; 3) separację (podział gruntów użytkowanych jednocześnie przez obszarnika i gromady); 4) indemnizację (odszkodowanie na rzecz obszarnika, które płaciło państwo albo rolnik, za pośrednictwem instytucji bankowych); 5) komasację; 6) regulację serwitutów - prawa do korzystania z gruntów i chłopskich, przysługujące wzajemnie chłopom i dziedzicom (np. prawo do wypasu bydła na pastwiskach czy zbierania w lasach drewna na opał ${ }^{10}$. Jak zauważa powołany autor, unormowania dotyczące reform agrarnych XIX wieku również współcześnie stanowią przedmiot rozstrzygnięć sądowych; w szczególności chodzi o wspólnoty gruntowe, dobra martwej ręki czy serwituty.

\section{B. Prawo agrarne instrumentem kształtowania ustroju rolnego}

Osoby specjalizujące się w prawie rolnym interesują się w sposób szczególny problemami ustroju rolnego, ponieważ prawne instrumentarium kształtowania ustroju dało podstawę do wyodrębnienia prawa agrarnego, będącego poprzednikiem prawa rolnego i żywnościowego. Pierwsza prezentacja teoretycznych zagadnień prawa agrarnego miała miejsce w podręczniku „Prawo agrarne”, opublikowanym przez Franciszka Longchamps w Warszawie w 1949 roku. Określając przedmiot wykładu Autor uznał, iż prawo agrarne jest to klasa wszystkich norm prawnych, które dotyczą władczego kształtowania ustroju rolnego w sposób celowy społecznie ${ }^{11}$. Prawo agrarne to normy prawne - a więc obowiązujące zdania powinnościowe - do-

9 Tamże, s. 38-41.

10 Por. R. Jastrzębski, Zagadnienia prawne reform agrarnych na ziemiach polskich w XX wieku, (w:) pracy zbiorowej: Kwestia agrarna. Zagadnienia prawne i ekonomiczne, P. Litwiniuk (red.), Warszawa 2016, s. 19-20.

11 F. Longchamps, Prawo agrarne, Warszawa 1949, s. 9. 
tyczące kształtowania ustroju rolnego, nie zaś samo kształtowanie. Ustrojem rolnym w tym określeniu jest układ form gospodarczych i prawnych korzystania z ziemi i ogół stosunków społecznych, współzależnych z tym układem. Prawo agrarne dotyczy władczego kształtowania ustroju rolnego; kształtowania go drogą władczych działań z zakresu administracji publicznej; prawo agrarne jest jednym z działów prawa administracyjnego. Prawo agrarne dotyczy kształtowania ustroju rolnego drogą przekształcania tych form korzystania z ziemi, które się przedtem wytworzyły w prawie cywilnym. Na koniec wypada określić stosunek zakresowy prawa agrarnego do prawa cywilnego. Zdaniem F. Longchamps, poza tym wszystkim, co wynika z prawa agrarnego, a więc z prawa, które dotyczy kształtowania ustroju rolnego w sposób celowy społecznie, korzystanie z ziemi jest poza tym zostawione pod rządem prawa cywilnego (i ewentualnie innych przepisów), a więc poza tym korzystający ma tę swobodę, która wynika z prawa cywilnego, przede wszystkim z prawa własności - bo to jest podstawową formą korzystania w prawie cywilnym $^{12}$.

Pamiętać należy, iż przytoczone poglądy F. Longchamps ogłoszone zostały w 1949 r., m.in. w oparciu o przegląd ustawodawstwa agrarnego z okresu dwudziestolecia międzywojennego. Natomiast w chwili odzyskania niepodległości w 1918 roku - zdaniem F. Longchamps - ,nie było na obszarach Polski żadnych przepisów prawnych, zmierzających do celowej przebudowy ustroju rolnego."13 Niektóre dzielnicowe przepisy dotyczące ograniczenia obrotu ziemią (tylko w b. zaborze pruskim i rosyjskim) nie miały na celu przebudowy ustroju rolnego, ale zachowanie pewnych, stanowego jeszcze pochodzenia, elementów tego ustroju. Poza tym korzystanie z ziemi podlegało powszechnym zasadom prawa cywilnego, które, choć różne w różnych pozaborczych dzielnicach, ujmowały przecież własność w jednaki niemal sposób, tj. odpowiadający w zasadzie gospodarce liberalnej i indywidualistycznej. „Druga połowa XIX wieku i początek XX wieku były zarazem okresem liberalizmu i prywatnego kapitalizmu w życiu gospodarczym i indywidualizmu $\mathrm{w}$ pojmowaniu stanowiska jednostki w grupie społecznej. Odpowiadała tym kierunkom właśnie klasyczna rzymska koncepcja własności”. ${ }^{14}$ Łącznie zatem: prawo własności według wzoru rzymskiego, liberalny i prywatno-kapitalistyczny system w ekonomii społecznej oraz indywidualizm w ustroju społecznym i państwowym tworzyły taką całość, w której rozporządzanie rzeczą było pozostawione swobodzie jednostki. Kto był właścicielem ziemi z jakiegokolwiek tytułu prawa cywilnego kupna, dziedziczenia, czy innego - mógł tę ziemię mieć w dowolnej ilości, mógł nią gospodarować według swojej woli, sprzedawać ją lub nabywać nową ziemię dowoli. Rozważania na temat roli prawa agrarnego w kształtowaniu ustroju rolne-

\footnotetext{
12 Tamże, s. 10-14.

13 Tamże, s. 15.

14 Tamże, s. 17.
} 
go F. Longchamps zamyka konstatacją: „Zanim się u nas rozpoczął proces nowoczesnego uspołecznienia własności, w szczególności przed powstaniem polskiego prawa agrarnego, prawa dzielnicowe nie zapobiegały np. w ogóle gromadzeniu (kumulowaniu) ziemi w rękach jednostek silnych gospodarczo, a nie zapobiegały skutecznie i powszechnie w całym Państwie, rozdrabnianiu i upadkowi gospodarstw chłopskich"15.

\section{Reforma rolna w II Rzeczypospolitej}

Ustrój rolny Polski, pozostawiony przez państwa zaborcze, był wynikiem długiego rozwoju panowania stanowego i kapitalistycznego na wsi, toteż wykazywał ogromną rozpiętość form gospodarczych, także pod względem wielkości, i katastrofalny stan własności chłopskiej. Powstanie państwa polskiego spowodowało, że sprawa przeprowadzenia reformy rolnej, zapisana w programach ówczesnych partii politycznych, w szczególności wywodzących się z ruchu ludowego, stanęła na porządku dziennym różnych ośrodków politycznych . Jednym, bodaj pierwszym dokumentem zapowiadającym reformę rolną był manifest Tymczasowego Rządu Ludowego Republiki Polskiej (Rządu Lubelskiego) z 7 listopada 1918 roku; manifest ten m.in. proklamował wniesienie do Sejmu Ustawodawczego projektu przymusowego wywłaszczenia i zniesienia wielkiej oraz średniej własności ziemskiej i oddanie jej w ręce ludu pracującego pod kontrolą państwową. Krótki był jednak żywot Rządu Lubelskiego, który rozwiązał się na żądanie Józefa Piłsudskiego. Manifest lubelski pozostał historyczną, lecz w praktyce bezowocną deklaracją polskiej lewicy demokratyczno-liberalnej, a ustawodawstwo polskie nadało przebudowie ustroju rolnego charakter reformy ewolucyjnej ${ }^{16}$.

Struktura agrarna polskiego rolnictwa odpowiadała sytuacji charakterystycznej dla gospodarek w państwach, w których występował problem tzw. głodu ziemi. Według spisu powszechnego w roku 1921 grupa gospodarstw o powierzchni do 5 ha stanowiła $64,6 \%$ ogólnej liczby gospodarstw, obejmując przy tym 14,8\% ogółu powierzchni ziemi; natomiast gospodarstwa o obszarze powyżej 50 ha (ich liczba wynosiła $0,9 \%$ ) posiadały $47,3 \%$ ogółu ziemi w Polsce; w województwach południowych aż 87,1\% ogółu gospodarstw znajdowało się w przedziale obszarowym do 5 ha ${ }^{17}$.

W praktyce, według oceny H. Świątkowskiego, ustawodawstwo związane z reformą rolną w okresie międzywojennym ogniskowało się wokół zagadnień:

15 Tamże.

16 Por. H. Świątkowski, Prawo rolne, Warszawa 1966, s. 20 i n.; Polityka agrarna. Podręcznik, S. Ignar (red.), Warszawa 1968, s. 68 i n.; W. Pańko, Prawo rolne, Katowice 1987, s. 40-43.

17 Por. Polityka agrarna. Podręcznik, s. 71. 
1) parcelacji tzw. wielkiej własności rolnej, czyli folwarków, oraz tworzenia z rozparcelowanych gruntów rolnych nowych gospodarstw chłopskich, bądź ich powiększenie (upełnorolnienie);

2) uwłaszczenia długoletnich posiadaczy gruntów, którzy nie otrzymali ich własności;

3) likwidacji serwitutów;

4) likwidacji wspólnot gruntowych ${ }^{18}$.

Gdy chodzi o reformę rolną w ścisłym znaczeniu, tj. parcelację wielkiej własności, wydano następujące regulacje ustawodawcze:

1) uchwałę Sejmu Ustawodawczego z dnia 10 lipca 1919 r. w przedmiocie zasad reformy rolnej ${ }^{19}$;

2) ustawę z dnia 15 lipca 1920 r. o wykonaniu reformy rolnej; ${ }^{20}$

3) ustawę z dnia 28 grudnia 1925 r. o wykonaniu reformy rolnej ${ }^{21}$.

Ad 1) Pierwsza regulacja miała charakter rezolucji i stanowiła kompromis stronnictw politycznych, zasiadających w Sejmie Ustawodawczym. Uchwała ta wytyczała zasady przyszłego ustroju i głosiła, że „,regulatorem władania ziemią ma być Państwo", że ziemie będą ,wykupowane drogą ustawowego przymusu... po cenie ustawą określonej”, że reforma zostanie przeprowadzona w drodze administracyjnej $^{22}$.

Uchwała Sejmu nie stanowiła prawa powszechnie obowiązującego, lecz zawierała postulaty de lege ferenda unormowań ustawodawczych. Maksymalny obszar gruntów folwarcznych, którego nie wolno przymusowo parcelować, wynosił od 60 do 180 ha, a dla części byłego zaboru pruskiego oraz ziem wschodnich wielkość ta mogła być podniesiona do 400 ha. Nadwyżka ponad maksimum miała zostać przymusowo wywłaszczona; wywłaszczenia oraz podziału ziemi miały dokonać organy państwowe. Obszar tworzonych i upełnorolnionych gospodarstw miał nie przekraczać 25 ha. W uchwale stwierdzono, że ,ustrój rolny Rzeczypospolitej Polskiej oprzeć się winien przede wszystkim na silnych, zdrowych i zdolnych do intensywnej produkcji gospodarstwach włościańskich, opartych na zasadzie prywatnej własności, różnego typu i wielkości”23. Ponadto uchwała dotyczyła przejścia własno-

18 Szerzej na ten temat: H. Świątkowski, Prawo rolne, op. cit., s. 20-35; A. Stelmachowski, Prawo rolne, op. cit., s. $42-47$.

19 Dz.Urz. Głównego Urzędu Ziemskiego RP 1920, s. 97-102; Sejm Ustawodawczy (1919-22), Druk Sejmowy nr 839.

20 Dz.U. Nr 70, poz. 462.

21 Dz.U. z 1926 r. Nr 1, poz. 1.

22 Por. F. Longchamps, Prawo agrarne, op. cit, s. 20.

23 Sejm Ustawodawczy (1919-1920), Druk Sejmowy nr 839, s. 1. 
ści lasów bez ograniczeń obszarowych na rzecz państwa, wyłączając lasy gminne i drobne lasy prywatne ${ }^{24}$.

Ad 2) Kolejnym aktem prawnym, przyjmującym już powszechnie znaną formę, była ustawa z dnia 15 lipca 1920 r. o wykonaniu reformy rolnej. W doktrynie zgodnie podkreśla się, że uchwalenie ustawy przez Sejm było związane z sytuacją militarną na froncie polsko-bolszewickim; w sytuacji zagrożenia niepodległości ustawa została przyjęta jednogłośnie, bez żadnej dyskusji, po krótkim przemówieniu sprawozdawcy. Zasady normatywne ustawy nie odbiegały daleko od omawianej poprzednio uchwały sejmowej (wykupowi podlegały nadwyżki ponad 180 ha, cena przymusowego wykupu ustalona została na 50\% ceny rynkowej $)^{25}$.

Według R. Jastrzębskiego, zasady reformy rolnej, zgodnie z ustawą z 1920 r. dotyczyły:

1) przymusowego wykupu ziemi wielkiej własności, przy czym pozostawiony został obszar poniżej pewnego maksimum ustawowego;

2) częściowej indemnizacji za wywłaszczoną przez państwo ziemię, która miała być wypłacana obszarnikowi;

3) określonych uprawnień dla żołnierzy, w szczególności inwalidów, oraz miejscowych robotników rolnych, w tym właścicieli gospodarstw karłowatych;

4) ograniczeń w zakresie obciążania czy też alienacji powstałych w wyniku reformy gospodarstw;

5) przeprowadzenia samej parcelacji przez organy państwowe;

6) ustawa, w porównaniu z wcześniejszą uchwałą, nie przewidywała już nacjonalizacji lasów ${ }^{26}$.

Tak się składa, iż regulacja prawna ustawy z 1920 roku nie jest szerzej omawiana czy komentowana w doktrynie, albowiem obowiązywała ona krótko - tylko do końca 1925 r. (została zastąpiona ustawą z 1925 roku o wykonaniu reformy rolnej), a nadto ,jej wykonanie było - zdaniem F. Longchamps - dość chwiejne, m.in. skutkiem pewnych braków redakcyjnych w samej ustawie"27. Chodzi tu głównie o ustalenia w przedmiocie odszkodowania, które miało być wypłacane obszarnikowi za wywłaszczoną ziemię. Ustawa przewidywała wypłacenie odszkodowania w wysokości połowy przeciętnej ceny rynkowej, czyli odszkodowanie w wysokości połowy ich wartości. I to zagadnienie budziło największe kontrowersje, zwłaszcza po wejściu w życie Konstytucji Rzeczypospolitej Polskiej z dnia 17 marca 1921 roku $^{28}$.

24 Szerokie omówienie uchwały z 1919 r. por. R. Jastrzębski, Zagadnienia..., op. cit., s. 22; por. także H. Świątkowski, Prawo rolne, op. cit., s. 22-24.

Por. W. Pańko, Prawo rolne, op. cit., s. 41; por. także H. Świątkowski, Prawo rolne, op. cit., s. 24

Por. R. Jastrzębski, Zagadnienia..., op. cit., s. 22-23 .

F. Longchamps, Prawo agrarne, op. cit, s. 20.

Dz.U. Nr 44, poz. 267. 
Ten właśnie moment został wykorzystany przez elementy konserwatywne zwalczające reformę rolną (podnoszono argument, że zasada niepełnego odszkodowania jest sprzeczna $z$ art. 99 Konstytucji marcowej) i przy jednoczesnym wykorzystaniu przewlekłej procedury doprowadzono do ,zablokowania” reformy rolnej ${ }^{29}$.

Zgodnie z postanowieniem art. 99 Konstytucji, Rzeczpospolita Polska uznaje wszelką własność, czy to osobistą poszczególnych obywateli, czy to zbiorową związków obywateli, instytucji, ciał samorządowych i wreszcie samego Państwa, jako jedną z najważniejszych podstaw ustroju społecznego i porządku prawnego oraz poręcza wszystkim mieszkańcom, instytucjom i społecznościom ochronę ich mienia, a dopuszcza tylko w wypadkach, ustawą przewidzianych, zniesienie lub ograniczenie własności, czy to osobistej, czy zbiorowej, ze względów wyższej użyteczności, za odszkodowaniem. Tylko ustawa może postanowić, jakie dobra i w jakim zakresie, ze względu na pożytek ogółu, mają stanowić wyłącznie własność Państwa, oraz o ile prawa obywateli i ich prawnie uznanych związków do swobodnego użytkowania ziemi, wód, minerałów i innych skarbów przyrody - mogą, ze względów publicznych, doznać ograniczenia. Ziemia jako jeden z najważniejszych czynników bytu narodu i państwa, nie może być przedmiotem nieograniczonego obrotu. Ustawy określą przysługujące Państwu prawo przymusowego wykupu ziemi, oraz regulowania obrotu ziemią, przy uwzględnieniu zasady, że ustrój rolny Rzeczypospolitej Polskiej ma się opierać na gospodarstwach rolnych, zdolnych do prawidłowej wytwórczości i stanowiących osobistą własność. Postanowienia Konstytucji brane były pod uwagę przy uchwalaniu ustawy z dnia 28 grudnia 1925 r. o wykonaniu reformy rolnej.

Ad 3) Ostatecznie ustawa z 1920 r. została uchylona przez ustawę z dnia 28 grudnia 1925 r. o wykonaniu reformy rolnej ${ }^{30}$; stanowiła ona swoisty kompromis polityczny między Związkiem Ludowo-Narodowym, Chrześcijańską Demokracją oraz PSL-Piast (tzw. pakt lanckoroński) ${ }^{31}$. W porównaniu do poprzednich aktów prawnych, ustawa z 1925 roku o wykonaniu reformy rolnej miała charakter umiarkowany ${ }^{32}$.

Ustawa przewidywała przejmowanie na cele reformy - za odszkodowaniem wypłacanym częściowo w gotówce, częściowo w papierach wartościowych - nadwyżek majątków obszarniczych ponad 180 ha użytków rolnych (w okręgach przemysłowych i podmiejskich - ponad 60 ha). Przepisy ustawy nakłaniały właścicieli

29 Por. A. Stelmachowski, Prawo rolne, op. cit., s. 42; R. Jastrzębski, Zagadnienia..., op. cit., s. 23-24; H. Świątkowski, Prawo rolne, op. cit., s. 24-25.

30 Dz.U. z 1926 r. Nr 1, poz. 1 z późn. zmianami.

31 Por. na ten temat: A. Ajnenkiel, Ustawodawstwo agrarne, (w:) Historia państwa i prawa Polski 1918-1939, cz. I, pod red. F. Ryszki, Warszawa 1962, s. 344 i n.

32 Por. R. Jastrzębski, Zagadnienia..., op. cit., s. 24. 
do dobrowolnej parcelacji dóbr; wywłaszczenie przez państwo było ostatecznością. Procedura przejmowania gruntów na cele reformy obejmowała 3 stadia:

1) stadium wstępne - ogłoszenie przez Radę Ministrów planu parcelacyjnego na następny rok kalendarzowy (do 15 lutego danego roku);

2) stadium przygotowawcze - $w$ razie nierozparcelowania, dobrowolnie kontyngentu gruntów przewidzianych w planie, Rada Ministrów ogłaszała wykaz imienny majątków podlegających przymusowemu wykupowi;

3) stadium realizacji - obejmujące sam wykup, które jednak nie mogło wystąpić wcześniej, niż po roku od dnia ogłoszenia wspomnianego wyżej wykazu.

Gdy chodzi o samą parcelację, mogła być ona przeprowadzona w trojaki sposób:

1) prywatnie przez właściciela lub za pośrednictwem upoważnionej instytucji powierniczej;

2) przez Bank Rolny (bank ten przyjmował także grunty prywatne do parcelacji komisowej);

3) przez właściwe organa administracji państwowej. Przy parcelacji dokonywanej przez organy administracji obowiązywał tryb publicznoprawny; ostateczne przejście własności następowało na podstawie orzeczenia wojewody. W dwóch pierwszych wypadkach parcelacja odbywała się przy wykorzystaniu formy cywilnoprawnej, z zastosowaniem obowiązujących przepisów dzielnicowych, jednakże pod kontrolą właściwych urzędów ziemskich, która obejmowała m.in. cenę nabycia. Jeżeli była ona wygórowana, można było odmówić zatwierdzenia planu parcelacji, nie można było natomiast administracyjnie obniżyć ceny ${ }^{33}$. Taki stan prawny krytycznie oceniał H. Świątkowski. Zdaniem autora, z punktu widzenia prawa cywilnego, istotna różnica między różnymi rodzajami parcelacji polegała na tytule przelania prawa własności na nabywców, którym przy parcelacji prywatnej jest kontrakt kupna-sprzedaży, natomiast przy parcelacji prowadzonej przez urzędy ziemskie jest to sui generis akt publiczno-prawny - orzeczenie okręgowego urzędu ziemskiego (wojewody), przenoszące w myśl art. 61 ustawy z $1925 \mathrm{r}$. własność. Przepis ten miał istotne znaczenie w stosunku do obowiązującego prawa cywilnego. Skoro bowiem własność przenosiło orzeczenie urzędu ziemskiego, to naruszona została zasada prawa cywilnego austriackiego i niemieckiego, że tylko przez wpis do księgi gruntowej nabywa się własność, zatem wpis do księgi gruntowej na podstawie takiego orzeczenia mógł mieć jedynie znaczenie deklaratywne ${ }^{34}$. 
Zapas ziemi przeznaczonej do parcelacji stanowiła pewna liczba majątków Skarbu Państwa oraz tzw. nadwyżki władania przekraczające obszary określone w ustawie. W założeniach ustawy było pozostawienie ziemiaństwa, jako klasy społecznej, a tylko „odjęcie ziemi z majątków przewyższających pewien obszar" ${ }^{35}$. Swoistą cechą systemu było to, że był wykonywany stopniowo: co roku władze rządowe ustalały plan parcelacyjny (kontyngent do rozparcelowania w następnym roku kalendarzowym w poszczególnych województwach), a następnie wykaz imienny (ustalenie indywidualne majątków, na których ciążył obowiązek parcelacyjny), w dalszej kolejności wykupywano nadwyżki, jeżeli nie zostały zbyte przez właściciela. Finansowanie reformy, tj. wypłata byłym właścicielom ceny wykupu (w 20\% gotówką, a w $80 \%$ obligacjami) i kredytowanie nabywania własności działek znajdowało się w gestii odrębnego Funduszu Obrotowego Reformy Rolnej. W ocenie F. Longchamps, ustawa z 1925 r. „nawet gdyby była sprawniej wykonywana, była tylko półśrodkiem i nie stanowiła rozwiązania sprawy ustroju rolnego"36.

Dla pełnej oceny reformy ustroju rolnego w okresie międzywojennym pomocne powinno być poinformowanie na temat licznego ustawodawstwa „okołoparcelacyjnego". Wskazać tu trzeba na ustawodawstwo organizujące osadnictwo na Kresach Wschodnich, zwłaszcza osadnictwo wojskowe, realizujące cele narodowościowe polityki agrarnej ${ }^{37}$, które miało na celu osadzenie osadników cywilnych i wojskowych narodowości polskiej. Osadnictwo to miało wzmacniać ochronę państwowej granicy wschodniej, co było zabiegiem w zupełności zrozumiałym.

Do pozytywnych stron polityki agrarnej okresu międzywojennego A. Stelmachowski zaliczał również uchylenie dawnego ustawodawstwa dyskryminacyjnego, wprowadzającego ograniczenia natury narodowościowej, czy też religijnej, jak również ustawodawstwa stanowego. Kończąc wlokące się ,,zaległości” z okresu pouwłaszczeniowego dokonano zniesienia serwitutów (nieznaczna reszta spraw niezałatwionych tego typu znalazła swój finał w okresie przeprowadzenia reformy rolnej PKWN 1944 r.) $)^{38}$.

W związku z reformą rolną pozostawał kompleks ustawodawstwa regulującego obrót ziemią. Największe znaczenie miało tymczasowe rozporządzenie Rady Ministrów z dnia 1 września 1919 r. normujące przeniesienie własności nieruchomości ziemskich ${ }^{39}$. Rozporządzenie to wymagało, dla skuteczności przeniesienia własności „nieruchomości ziemskich”, zgody właściwego organu administracyjnego. Rozporządzenie miało na celu kontrolę obrotu tymi wszystkimi nieruchomo-

35 Takiego określenia używa F. Longchamps, Prawo agrarne, op. cit, s. 21.

36 Tamże, s. 22.

37 Por. ustawa z dnia 17 grudnia 1920 r. o nadaniu ziemi żołnierzom Wojska Polskiego (Dz.U. z 1921 r. Nr 4 , poz.18).

38 Por. A. Stelmachowski, Prawo rolne, op. cit., s. 43-47.

39 Dz.U. Nr 73, poz. 428 z późn. zm. 
ściami, które miały być przeznaczone na cele reformy rolnej. Od obowiązku uzyskania zezwolenia zwolnione były nieruchomości będące przedmiotem własności „włościańskiej (rustykalnej)”; jak wyjaśniło orzecznictwo Sądu Najwyższego dotyczyło to nieruchomości nie przekraczających górnej wysokości działek nadawanych z reformy rolnej ${ }^{40}$. Nadto została wydana ustawa z dnia 14 kwietnia 1937 r. o ograniczeniu obrotu nieruchomościami powstałymi z parcelacji ${ }^{41}$. Do ustaw porządkujących gospodarowanie ziemią rolniczą zaliczyć należy ustawę z dnia 31 lipca $1923 \mathrm{r}$. o scalaniu gruntów ${ }^{42}$; ustawę z dnia 4 maja 1938 r. o uporządkowaniu wspólnot gruntowych ${ }^{43}$ oraz grupę aktów normatywnych regulujących kwestie uwłaszczenia drobnych dzierżawców rolnych i podobnych kategorii ${ }^{44}$.

Prezentując regulację prawną z zakresu prawa agrarnego w okresie międzywojennym, warto zwrócić uwagę, iż po wejściu w życie ustawy o wykonaniu reformy rolnej z 1925 r. Minister Reform Rolnych powołał do życia Komisję Uporządkowania Ustawodawstwa Agrarnego, której przewodniczącym został Władysław Leopold Jaworski; efektem jej działalności był Projekt Kodeksu Agrarnego, który ukazał się w 1928 r. ${ }^{45}$ Przygotowanie tego projektu świadczy o znaczeniu problemu kształtowania ustroju rolnego dla władz niepodległego kraju; natomiast niewykroczenie poza fazę samego projektu uznać należy za słuszne zaniechanie, ponieważ każda kodyfikacja jakiejś dziedziny oznacza jej petryfikację na dzień kodyfikacji, natomiast kształtowanie ustroju rolnego w Polsce wymagało jeszcze wielu zmian, o czym świadczą m.in. zmiany ustawodawcze co do pozycji dzierżawców rolnych.

\section{Ocena reform rolnych okresu międzywojennego}

Jak każde zjawisko społeczno-gospodarcze o istotnym znaczeniu dla kształtowania ustroju gospodarczego, w tym przypadku ustroju rolnego, reformy spotykają się ze złożonymi, zróżnicowanymi ocenami, co jest zrozumiałe zwłaszcza, jeśli uwzględni się zróżnicowanie horyzontu czasowego dokonywanych ocen. Większość oceniających dynamikę przemian zwraca uwagę, że na wykonanie reformy rolnej duży wpływ wywarł ogólnoświatowy kryzys gospodarczy lat 1929-33. Związany z nim był drastyczny spadek cen towarów rolnych, co powodowało zmniejszenie dochodowości gospodarstw rolnych oraz cen nieruchomości ziemskich; nadto wzrosło realne zadłużenie gospodarstw rolnych, z którym wiązało się rolnicze ustawodawstwo oddłużeniowe o charakterze moratoryjnym ${ }^{46}$.

40

41

42

43

44

45

46

Por. S. Breyer, Przeniesienie własności nieruchomości, Warszawa 1966, s. 215 i n.

Dz.U. Nr 36, poz. 272.

Dz.U. z 1927 r. Nr 92, poz. 833 z późn. zm.

Dz.U. Nr 33, poz. 290.

Por. F. Longchamps, Prawo agrarne, op. cit, s. 23-24.

Fakt ten odnotowuje R. Jastrzębski, Zagadnienia..., op. cit., s. 25, odsyłając do opracowania W.L. Jaworski, Projekt Kodeksu Agrarnego, Warszawa 1928.

Por. H. Świątkowski, Prawo rolne, op. cit., s. 31 i n. 
Gdy chodzi o dokonania prac parcelacyjnych, to w latach 1919-1938 pracami tymi objęte zostało około 735 tys. gospodarstw, z których utworzono około 154 tys. gospodarstw samodzielnych, scalaniem objęto 859 tys., w tym likwidacją serwitutów 280,5 tys. Natomiast 68,5\% parcelowanego obszaru rozparcelowali sami obszarnicy, zaś około $30 \%$ nabywców otrzymało ziemię bezpośrednio z rąk państwa. $\mathrm{Z}$ powyższego wynika, że reforma rolna tego okresu nie przyniosła zasadniczej zmiany w strukturze polskiej wsi. Według szacunków, własność chłopska powiększyła się bowiem jedynie o 13\%, a powierzchnia majątków obszarniczych zmniejszyła się o $16 \%{ }^{47}$. Ustawa o reformie rolnej nie pozwalała „spieszyć się” z parcelacją. Roczny kontyngent ziemi przeznaczony na parcelację określała na 200 tys. ha. W praktyce zamiast 200 tys. ha parcelowano przeciętnie w okresie dwudziestolecia 132.740 ha, czyli $65 \%$ przewidywanej ilości. Biorąc pod uwagę ogólny obszar gruntów podlegających parcelacji, wynoszący ok. 5.500 tys. ha, to parcelacja w takim tempie musiałaby przeciągnąć się do $1965 \mathrm{r}^{48}$

Zdaniem F. Longchamps, biorąc w całości okres dwudziestolecia, reforma rolna - przedmiot wielu sporów, rozgrywek politycznych i krzyżowania różnych wpływów - nie została dokonana, nawet w imię tych założeń, które przyjęto dla ustawy z dnia 28 grudnia 1925 r. $^{49}$ Według A. Stelmachowskiego, patrząc z perspektywy czasu na reformę międzywojennego otrzymujemy obraz bardzo złożony. Nawet gdyby reforma była przeprowadzona w sposób radykalny, i tak nie mogła rozwiązać problemu; zapas ziemi obszarniczej był niewystarczający dla zaspokojenia głodu ziemi. Zasadniczym momentem paraliżującym poczynania w dziedzinie reformy był słaby stan uprzemysłowienia kraju, silne uzależnienie od kapitału zagranicznego i niemożność odpływu nadwyżek siły roboczej ze wsi. Biedota wiejska nie miała środków na zakup ziemi, korzystała więc z reformy rolnej w sposób jawnie niewystarczający; natomiast wśród nabywców był wielu bogatych chłopów; ok. 10\% nabywców stanowili nierolnicy ${ }^{50}$.

Interesująca jest ocena byłego ministra rolnictwa i reform rolnych Juliusza Poniatowskiego, który już po II wojnie światowej stwierdził, że „reforma rolna w niepodległej Polsce ani się nie stała historycznym aktem przymierza odrodzonego państwa z zaniedbywaną dotychczas najliczniejszą grupą narodu - jak to marzyli sobie społecznicy, ani nie spełniła tak wielkich nadziei - jakie w niej pokładał lud wiejski, ani nie odegrała tak ważnej roli gospodarczej - jaką spełnić mogła, ...jej niedokończenie, jej powolne sączenie się poprzez dziesięciolecia, jej metoda przeważnie uchylająca bezpośrednie zetknięcie z państwem, a skazująca na targ o kupno ziemi

47 Por. R. Jastrzębski, Zagadnienia..., op. cit., s. 26 i tam powołana literatura. Według W. Pańki, Prawo rolne, op. cit., s. 43, tzw. wielka własność zmniejszyła swój stan posiadania o 7\%; podobnie H. Świątkowski, Prawo rolne, op. cit., s. 33.

48 Por. H. Świątkowski, Prawo rolne, op. cit., s. 33 i n.

49 F. Longchamps, Prawo agrarne, op. cit, s. 22.

50 Por. A. Stelmachowski, Prawo rolne, op. cit., s. 45 i n. 
od dziedzica, wreszcie jej beztroskie i twarde zaniedbanie pomocy finansowej w latach zagospodarowania - pozbawiały ją charakteru pamiętnego państwowego aktu" ${ }^{11}$. Z osądem tym trzeba się zgodzić, ponieważ mało kto uznaje, że przeprowadzenie reformy rolnej było aktem politycznym, należącym do symboli odzyskania niepodległości w 1918 roku.

Stało się tak m.in. i z tego względu, że efekty ewolucyjnie przeprowadzanej reformy parcelacyjnej w latach międzywojennych, w ocenie politycznej społeczeństwa polskiego znalazły się niejako ,pod przykryciem" radykalnej reformy rolnej Polskiego Komitetu Wyzwolenia Narodowego, przeprowadzonej po II wojnie światowej. To ta reforma pozostała w świadomości narodu jako jeden z aktów konstytuujących ustrój społeczno-gospodarczy, choć oparta była na odmiennych założeniach ideologiczno-politycznych, a władzy, która reformę zrealizowała, nie można uznać za suwerenną władzę niepodległej Polski. Ściśle rzecz biorąc na reformę ustroju rolnego wpływ miały dwie wielkie akcje: przebudowy ustroju na dawnych (przedwojennych) ziemiach polskich oraz osadnictwo na Ziemiach Odzyskanych ${ }^{52}$. Co do osadnictwa na Ziemiach Odzyskanych, miało ono charakter akcji ogólnonarodowej, o wielkim znaczeniu politycznym i nie budziło zasadniczych różnic poglądów w społeczeństwie. Natomiast akcja reformy rolnej w państwie polskim po II wojnie miała charakter niezwykle radykalnej reformy ustrojowej ${ }^{53}$. Radykalizm reformy polegał przede wszystkim na przejęciu na jej cele, na własność państwa, nieruchomości ziemskich, bez odszkodowania dla dotychczasowych właścicieli. Jak stwierdzał F. Longchamps, przeprowadzenie reformy rolnej było likwidacją klasy ziemiańskiej, uwłaszczeniem mas bezrolnych i upełnorolnieniem gospodarstw karłowatych, małorolnych i średniorolnych ${ }^{54}$. Reforma przeprowadzona została wyłącznie przy wykorzystaniu, dla jej realizacji, mechanizmów administracyjnoprawnych czyli decyzji administracyjnych, bez jakichkolwiek możliwości odwołania się do niezawisłych sądów, czy też sądowej kontroli decyzji administracyjnych (Naczelny Sąd Administracyjny funkcjonuje dopiero od 1980 r.). Prawdą jest, iż reforma rolna lat 1944-48 spowodowała zaspokojenie dążeń wielu do „zaspokojenia głodu ziemi”, jednakże - i to trzeba otwarcie stwierdzić - reforma jednocześnie pogorszyła strukturę obszarową indywidualnych gospodarstw rolnych; do dnia dzisiejszego jednym z celów strukturalnej polityki rolnej jest poprawa średniej wielkości obszarowej indywidualnego gospodarstwa rolnego, która uległa istotnemu pogorszeniu wskutek reformy lat 1944-46. Pamiętać należy także o likwidacji ziemiaństwa jako klasy społecznej. Najczęściej trudno jest o jed-

J. Poniatowski, Cele i założenia Reformy Rolnej w 20-leciu Niepodległości, Warszawa 2004, s. 31.

Dekret z dnia 6 września 1946 r. o ustroju rolnym i osadnictwie na obszarze Ziem Odzyskanych i b. Wolnego Miasta Gdańska (Dz.U. Nr 49, poz. 279); dekret pomyślany był jako lex specialis w stosunku do dekretu o reformie rolnej.

Dekret o przeprowadzeniu reformy rolnej z dnia 6 września 1944 r. (Dz.U. Nr. 4, poz. 1). Szerzej na temat tej reformy rolnej A. Stelmachowski, Prawo rolne, op. cit., s. 60-65.

F. Longchamps, Prawo agrarne, op. cit, s. 80-81. 
noznaczne oceny poszczególnych reform rolnych. Już w 1918 roku Franciszek Bujak pisał, że „reforma rolna jest przebudową podwalin bytu narodowego, która może będzie trwała setki lat i przez cały ten okres będzie na ten byt niezmiernie silnie oddziaływała”. Autor ten dodawał niezwykle istotną uwagę, że „reforma nie może być przeprowadzona w tym duchu, aby kosztem jednej warstwy społecznej wzbogacać drugą w imię jakiejś sprawiedliwości dziejowej. Nie o porachunki bowiem i spłaty długów za przeszłość, ale jedynie o najlepsze urządzenie stosunków na przyszłość powinno tu chodzić, jak we wszystkich reformach społecznych”, zaś „celem bezwzględnym i wynikiem koniecznym musi być naprawa ustroju rolnego" 
Keywords: agricultural reform, evolutionary reform, revolutionary reform, parcel, agrarian structure, agrarian law - regulating the issue of agricultural reform

Restructuring of agricultural system after regaining independence in 1918 was of the nature of the evolutionary reform that consisted in the process of dividing surpluses over the determined size of the farms into smaller items. The reform was carried out by administrative methods and the provisions governing the reform initiated Polish agrarian law. However, the revolutionary (expropriation) reform that was carried out after the Second World War (1944-1946) remained in remembrance of the Poles.

\section{Bibliografia:}

Breyer S., Przeniesienie własności nieruchomości rolnych, Warszawa 1966.

Bujak F., O naprawie ustroju rolnego w Polsce, Kraków 1918.

Ignar S. (red.), Polityka agrarna, Podręcznik, Warszawa 1968.

Jastrzębski R., Zagadnienia prawne reform agrarnych na ziemiach polskich w XX wieku, (w:) praca zbiorowej, Kwestia agrarna, Zagadnienia prawne i ekonomiczne, P. Litwiniuk (red.), Warszawa 2016, s. 17-37.

Jaworski W.L., Projekt Kodeksu Agrarnego, Warszawa 1928.

Kula W., Historia gospodarcza Polski w dobie popowstaniowej 1864-1918, Warszawa 1947.

Kula W., Wstęp, (w:) Materiały do dziejów uwłaszczenia w Królestwie Polskim, oprac. K. Śreniowska, S. Śreniowski, Wrocław 1961.

Longchamps F., Prawo agrarne, Warszawa 1949.

Pańko W., Prawo rolne, Katowice 1987.

Poniatowski J., Cele i założenia Reformy Rolnej w 20-leciu Niepodległości, Warszawa 2004.

Ryszka F. (red.), Historia państwa i prawa Polski, 1918-1939, cz. I, Warszawa 1962.

Śreniowski S., Uwłaszczenie chłopów w Polsce, Warszawa 1956 r.

Selwa J., Stelmachowski A., Prawo rolne, Warszawa 1970.

Świątkowski H., Prawo rolne, Warszawa 1966. 